\title{
Reproductive Biology of the Three Spot Swimming Crab (Portunus sanguinolentus) Occurring in the Coastal Waters off Negombo, Sri Lanka with Novel Approach to Determine the Maturity Stage of Male Gonads
}

\author{
H.B.U.G.M. Wimalasiri ${ }^{*}$, D.C.T. Dissanayake \\ Department of Zoology, University of Sri Jayewardenepura, Sri Lanka \\ *udshikamanike@gmail.com
}

\begin{abstract}
The reproductive biology of Portunus sanguinolentus (Three Spot Swimming Crab) was investigated in the coastal waters off Negombo, Sri Lanka from February 2014 to January 2015. Reproductive activity was assessed using macroscopic and microscopic observations of gonad characteristics, trends of gonad indices, size at first sexual maturity and differences in the monthly sex ratio. Though $P$. sanguinolentus females have higher body weight than males, carapace length, carapace width or body weight of males and females were not significantly different (Mann-Whitney test, $\mathrm{p}>0.05$ ). Ovigerous females were observed throughout the year, confirming that they are continuous spawners however, peak spawning was in October. Percentage Gonadosomatic Index (GSI) of females is significantly higher than the males ( $t$-test; $\mathrm{p}<0.05 ; \mathrm{df}=193$ ) and GSI values ranged from 0.02 to 3.69 in males and 0.12 to 9.44 in females. Sex ratio of $P$. sanguinolentus population fluctuated seasonally and significantly high male to female sex ratio was observed in October 2014 ( $\chi^{2}$ test). Size at first sexual maturity $\left(\mathrm{Lm}_{50}\right)$ was estimated at 9.75 and $8.90 \mathrm{~cm}$ (carapace width, $\mathrm{CW}$ ) for males and females, respectively. Three types of external egg masses; stage I, II and III were identified based on colour and size of the berried eggs. The mean diameter $(\mu \mathrm{m})$ of eggs in each stage was reported as $253.8 \pm 3.19,281.8 \pm 6.79,316.5 \pm 9.78$, respectively. The average fecundity of $P$. sanguinolentus varied from $2.04 \times 10^{4}$ to $1.24 \times 10^{6}$ and it increased with increasing CW. Present study proposes a new method to identify mature and immature males by using their external characteristics. Accordingly, in mature males, blue color patches can be observed on the ventral side of chelar propodus and merus but this colour pattern is not prominent in immature males and absent in mature females.
\end{abstract}

Keywords: Portunus sanguinolentus, Sri Lanka, Chelar propodus, Merus, Size at first sexual maturity 